UDC 621.3:629.4:625.42

A. O. Sulym ${ }^{1}$, Cand. Sc. (Tech.), orcid.org/0000-0001-8144-8971, O.V. Fomin ${ }^{2}$, Dr. Sc. (Tech.), Assoc. Prof., orcid.org/0000-0003-2387-9946, P. O. Khozia ${ }^{1}$, Cand. Sc. (Tech.), orcid.org/0000-0001-8948-6032, A. G. Mastepan ${ }^{3}$, orcid.org/0000-0002-8610-1093
DOI: $10.29202 /$ nvngu/2018-5/8

1 - State Enterprise "Ukrainian Scientific Railway Car Building Research Institute", Kremenchuk, Ukraine, e-mail: sulim1.ua@gmail.com; pavel.ua@gmail.com

2 - State University of Infrastructure and Technology, Kyiv, Ukraine, e-mail: fomin1985@ukr.net

3 - Ukrainian State University of Railway Transport, Kharkiv, Ukraine, e-mail: antonua86@gmail.com

\title{
THEORETICAL AND PRACTICAL DETERMINATION OF PARAMETERS OF ON-BOARD CAPACITIVE ENERGY STORAGE OF THE ROLLING STOCK
}

In view of the stage-by-stage increase of electricity tariffs, further development of metro rolling stock is impossible without application of modern energy saving technologies and energy efficient systems.

Purpose. Further development of metro rolling stock equipped with regenerative braking systems with regard to increase in its energy efficiency due to introduction of an on-board energy storage units of capacitance type with account of changes in daily operational condition.

Methodology. Three approaches for determination of parameters of on-board capacitive energy storage are suggested based on the results of experimental research studies, and also using the statistical methods of data processing, analysis and probability theory methods. The suggested approaches include successive implementation of the following combined stages: a choice of operation area and a model of metro rolling stock, determination of normal daily operational environment, experimental research on energy power processes during different daily operation of rolling stock, mass-data processing, histograming and determination of on-board capacitive energy storage parameters using the suggested criteria.

Findings. Energy power processes were registered under normal daily operational conditions of rolling stock equipped with regenerative braking systems on Sviatoshynsko-Brovarska line of PU "Kyiv Metro". Instantaneous and average energy power and an amount of electric power for each regenerative braking process of a train were measured. According to the results of mass-data processing, probabilistic characteristics are built in the form of histograms of the density distribution of average power and regenerative energy amount within three suggested approaches. Major technical parameters of on-board capacitive storage, i.e. nominal and maximal power, operational and total energy capacity are determined with the aid of the above-mentioned approaches for specified operational conditions of the metro train.

Originality. For the first time approaches for determination of parameters of on-board capacitive energy storage for metro train according to the analysis of distribution density of average power and amount of regenerated electricity are proposed. Research on determination of parameters of on-board capacitive energy storage for metro rolling stock with brake regenerative systems got further development.

Practical value. The suggested approaches can be used for construction of metro rolling stock with on-board capacitive energy storage.

Keywords: on-board capacitive energy storage, metro rolling stock, regenerative braking system

Introduction. Currently in Ukrainian, underground transportation of passengers is provided mainly by wagons with commutator motors, contact power control and rheostatic braking, which is characterized by high specific power consumption per unit of transportation work. The use of rheostatic braking on wagons leads to a significant increase in the total amount of consumed electricity by subway due to significant energy losses in the pullout rheostats [1].

In recent years modernization of existing and the purchase of new wagons have taken place in the subways of Ukraine in order to reduce the cost of electric energy for haulage of trains, increase the comfort level of passengers and machinists, increase the reliability of the electric equipment of wagons, reduce the amount of scheduled works and maintenance, extend the terms of

(c) Sulym A. O., Fomin O. V., Khozia P. O., Mastepan A. G., 2018 rolling stock operation. Upon that, new requirements for both the improvement of technical and economic indicators and the increase in the level of safety [2], including the improvement of dynamic qualities, are put forward [3]. The main differences between the newly created and upgraded rolling stock is the use of an asynchronous alternating current drive, microprocessor control system, as well as the introduction of other energy saving equipment and technologies, primarily recovery systems [4]. According to the results of research [5] it is known that upgrading the existing rolling stock in relation to the five cars coupling allows reducing the consumption of electric power for traction by $35-40 \%$. Therefore, now energy saving and energy efficiency measures of rolling stock are being implemented in the domestic subways. At the same time it is expedient to increase energy efficiency of the rolling stock of the subway as well as its other types (locomotives, passenger 
and freight cars) for railway transport by means of constructive improvements [6] in accordance with the directions specified in the work [7]. The implementation of the proposed scientific approaches will significantly improve resource efficiency [8] on rail transport and thus improve the efficiency of its operation.

As it is known from research [9] there are reserves of additional savings in the rolling stock of the subway with the recuperation systems, which mainly exist due to the inefficient use of recuperative braking in the absence of consumers of this electricity in the recuperation zone. Under conditions of real exploitation, many factors influence the amount of used energy for recovery [10]. Among the main ones [11] we can distinguish the following: the traffic density in the recuperation zone, the motion mode of other electricity consumers, the distance between the stations, the grading of track and resistance to movement [12], which is directly dependent on the cost of traction transmission [13] and the optimal profile line of driving [14]. It is known [15] that in the real conditions of operation of the rolling stock of the subway, the amount of electric energy recuperated to the contact network is 10-20\%; the amount of excess electricity that is emitted in the form of heat on the brake resistors is at the level of 20-30\%, which is consumed for draft. The research findings [16] show that the electricity of recuperative braking, which is generated by the contact network, is far from being fully realized. Much of this electricity is excess and dissipated in the form of heat on the bus lines of the contact network during transportation to other consumers. Consequently, taking into account the above fact, the efficiency of the use of electric energy of recuperative braking makes only $5-10 \%$ of the amount of consumed electricity by traction [17]. Thus, according to the existing infrastructure of the traction energy supply system of the underground, reserves of energy saving make up to $30 \%$ of the amount of consumed electricity by traction.

As it is known from the results of research [18] one of the methods for increasing the utilization of electricity from recuperative breaking and, accordingly, energy efficiency on the rolling stock of the underground with the systems of recuperation, is the introduction of buffer capacitive storage on it [19]. At present a large number of domestic and foreign [20] scientists are engaged in research on the introduction of energy storage devices on the rolling stock of the subway. Analysis of these studies allowed establishing that one of the open issues remains the choice of parameters of the capacitive storage with regard to the real conditions of operation of the rolling stock of the underground with the systems of recuperation.

The objective of the article is to determine the parameters of the on-board capacitive energy storage including changes in the daily operating conditions of rolling stock of the subway through the application of a new scientific approach.

Research methodology. Presentation of the main research. The main idea of the proposed approaches is to determine the parameters of the on-board capacitive energy storage on the basis of the analysis of the charac- teristics of the power distribution density and the amount of electric recovered energy. The proposed approaches have the following common stages:

- the choice of operation area and the model of rolling stock of the underground;

- the definition of typical operating conditions that change during the day (schedule of traffic, load of cars);

- the experimental research on energy processes during typical conditions of rolling stock operation;

- analysis of the received data and determination of the range of power change and amount of recuperative braking power;

- histograming according to the results of analyzing the received data with regard to the proposed approaches;

- the determination of working energy intensity, nominal and maximum power of the on-board capacitive energy storage assuming the proposed criteria.

The first stage. The area between the terminal stations of the Sviatoshynsko-Brovarska line of the PU "Kyiv Metro" was selected for the research. The rolling stock is a five-car coupling train with an asynchronous traction drive and recuperation systems, in which the main wagons are engineless, while intermediate ones are motorized.

The second stage. The following typical conditions of operation of the subway train during the day are accepted: three and two full circles within the "off-peak" traffic schedule, respectively, at nominal and maximum loading; one and two full circles within the "peak" traffic schedule, respectively, at nominal and maximum load; one full circle with the observance of "off-peak" traffic schedule with minimal load.

The third stage includes the experimental research on energy processes under typical operating conditions, which was carried out using an investigation complex, that consists of the above-mentioned rolling stock and measuring installed system on its board. The measuring system was developed by experts of the research group of electric and traction-energy equipment.

The metering system was created by the specialists of the research team of the electrical and tractive power equipment of State Enterprise "Ukrainian Scientific Railway Car Building Research Institute" for the study of energy processes between the contact network and the train in the real conditions of its operation. The metering system consists of a personal computer, an analog-digital converter, a switching unit, a unit of coordination and measuring sensors. Data processing on a personal computer is carried out using certified software. The metering system involves receiving, displaying and storing the data from measurement gauges that are installed on the experimental train.

According to the results of these studies, oscillograms of the voltage of the contact network (current collector), current and speed of the composition at its typical operating conditions during the day were obtained.

The fourth stage involves the processing of data. The following indicators for recuperative braking modes are defined according to the data processing results which were obtained during the typical rolling stock operating conditions: speed of start of braking $\left(V_{g a l}\right)$, average and 
maximum recuperative braking power $\left(P_{\text {ave }}, P_{\max }\right)$, as well as amount of electric energy of recuperation $(A)$.

The instantaneous power of the rolling stock for the recuperative braking mode is determined by the formula

$$
p(t)=u(t) \cdot i(t) .
$$

The average power of recuperative braking power is determined by the formula [9]

$$
P_{\text {ave }}=\frac{1}{N} \cdot \sum_{k=1}^{N} P_{k}=\frac{1}{N} \cdot \sum_{k=1}^{N} U_{k} \cdot I_{k},
$$

where $N$ is the total number of discretization intervals in the research process; $U_{k}, I_{k}$ are the value of the voltage and current at time $\mathrm{t}_{\mathrm{k}}$ during the discretization of signals $u(t)$ and $i(t)$.

The amount of electricity recuperation is determined by the formula [9]

$$
A=\frac{\int_{0}^{T} P d t}{3.6 \cdot 10^{6}}=\frac{\sum_{k=1}^{T} U_{k} \cdot I_{k} \cdot \Delta t}{3.6 \cdot 10^{6}},
$$

where $T$ is time (period) of research; $\Delta t$ is interval of quantization of signals processing $u(t)$ and $i(t)$, that is equal to $0.5 \mathrm{~s}$ in this work.

The results of processing data for typical conditions of train operation are given in Table 1.

At the fifth stage according to the data in Table 1, probabilistic characteristics in the form of histograms of the distribution density of average power and the amount of recuperation electricity were made for three different proposed approaches (Figs. 1-3).

The first approach involves creating histograms for the most common operating conditions during the day. In the presence of several conditions of operation with the same time effect, the construction of histograms is carried out for a condition with a maximum total amount of electric energy recuperative braking.

The second approach involves the maximum mode of energy exchange, which in this case corresponds to the "peak" traffic schedule of trains with maximum loading.

The third approach involves creating histograms taking into account all typical conditions of operation of the train and their number during the day.

The histograms were created in the following order:

- determination of the range of changes in the average power and amount of recuperative braking power for each of these approaches;

- splitting of the range into several subbands;

- determination of the density of distribution of average power and the amount of the recuperation electricity by the formula

$$
f=\frac{n_{i}}{n}
$$

where $n_{i}$ is the number of brakings for the subband under study; $n$ is the total quantity of breaking;

definition of the distributive law of the power and the amount of electricity from the recuperation by approximating the density data for the received subbands.
The following was determined according to the data analysis in Table 1 and Figs. 1-3:

- the average power of the recuperative electric power for the first approach is in the range of $326 \ldots 1924 \mathrm{~kW}$; for the other is $465 \ldots 2009 \mathrm{~kW}$; for the third one is $181 \ldots$ $2220 \mathrm{~kW}$; the amount of electricity for the first approach is in the range of $0.87 \ldots 44.4 \mathrm{~kW} \cdot \mathrm{h}$; for the other is $1.92 \ldots 42.48 \mathrm{~kW} \cdot \mathrm{h}$; for the third one is $0.58 \ldots 43.99 \mathrm{~kW} \cdot \mathrm{h}$;

- the required energy intensity of the capacitive energy storage for maintaining the full capacity of the regenerative braking power should be at least $44.4 \mathrm{~kW} \cdot \mathrm{h}$ for the first approach; for the second one it is not less than $44.61 \mathrm{~kW} \cdot \mathrm{h}$; for the third one it is not less than $45.95 \mathrm{~kW} \cdot \mathrm{h}$;

- the density of the distribution of average power and the amount of electricity recuperation varies according to the normal law.

According to the results of the analysis of the instantaneous power values for recuperative braking modes, the maximum capacity recorded for the first approach was $3112 \mathrm{~kW}$; for the second one it is $3835 \mathrm{~kW}$; for the third one it is $3879 \mathrm{~kW}$.

The sixth stage involves determination of the parameters of the on-board capacitive energy storage according to the proposed approches. The criteria for choosing the parameters of on-board capacitive energy storage are as follows:

- determination of nominal power is carried out at the average power of the electric power of the recuperative braking of the train on the indicated area;

- the maximum power of the capacitive energy storage is chosen for the maximum (peak) value of the instantaneous power of the recuperative braking power;

- determination of the working energy intensity of the capacitive energy storage is carried out according to the law of distribution of the amount of recuperative electricity. Under the uniform distribution law, the energy intensity is determined by the maximum value of the amount of electric recovered energy $\left(A_{\max }\right)$, with other standard laws (triangular, normal, exponential, and others) is by the average $\left(A_{\text {ave }}\right)$ taking into account the mean-square deviation $(\sigma)$, that is, $A_{\text {ave }}+\sigma$. The "+" sign in the criterion shows that one value of the energy intensity of the capacitive energy storage is determined, which takes into account the maximum density distribution of the amount of electricity.

The average values are determined for the confidence interval of the sample taken at 0.95 . Values that do not fall into the confidence interval are considered to be a failure and, when determining the average, are not taken into account.

Based on the above, confidence intervals are defined for the average power and amount of recuperative electricity. In this case the following values were excluded for the first approach: $44.4 \mathrm{~kW} \cdot \mathrm{h}$; for the second one it is $465 \mathrm{~kW}$ and $42.48 \mathrm{~kW} \cdot \mathrm{h}$; for the third one it is 22.54 ; $42.13 ; 42.48 ; 42.86 ; 43.99 \mathrm{~kW} \cdot \mathrm{h}$.

The results of the research on the determination of the average value of the amount of electric energy of the recuperation $\left(A_{\text {ave }}\right)$, the mean square deviation $(\sigma)$, the rated power of the capacitive energy storage $\left(P_{\text {nom.CES }}\right)$, 


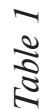

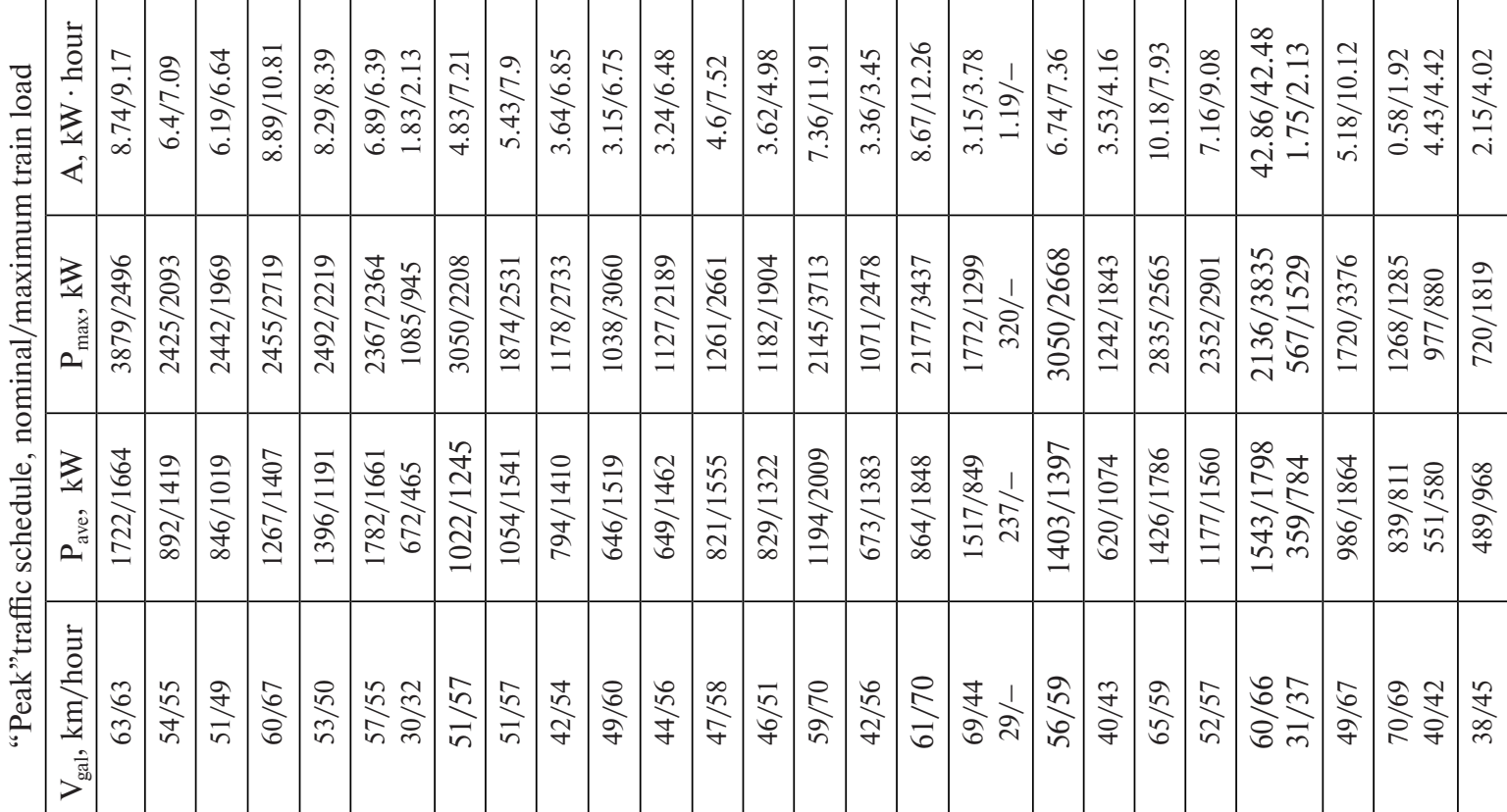

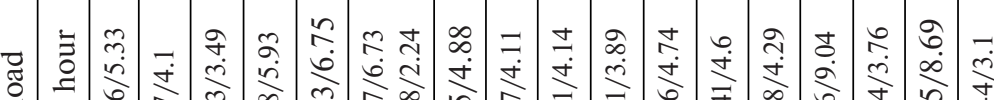

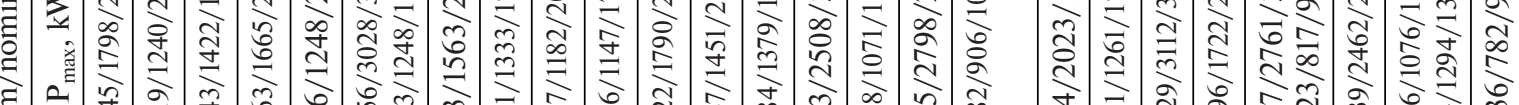

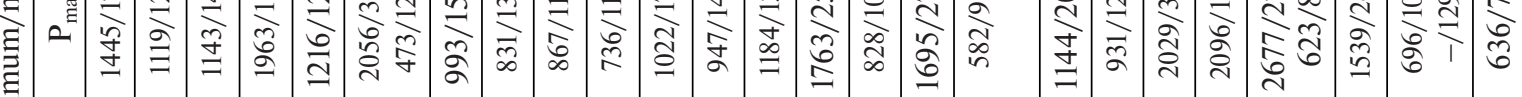
当

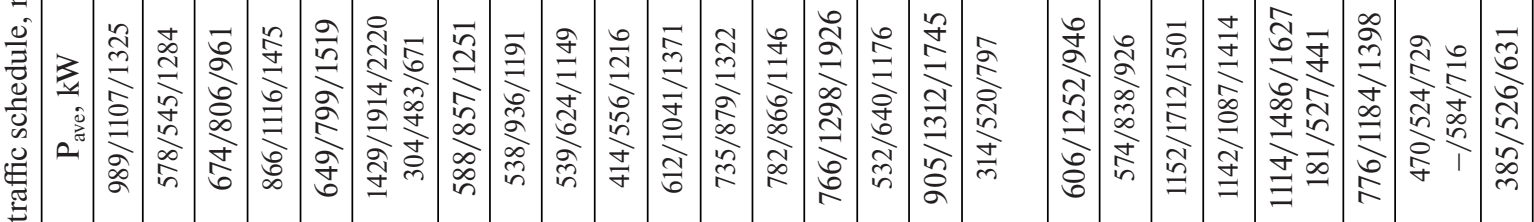

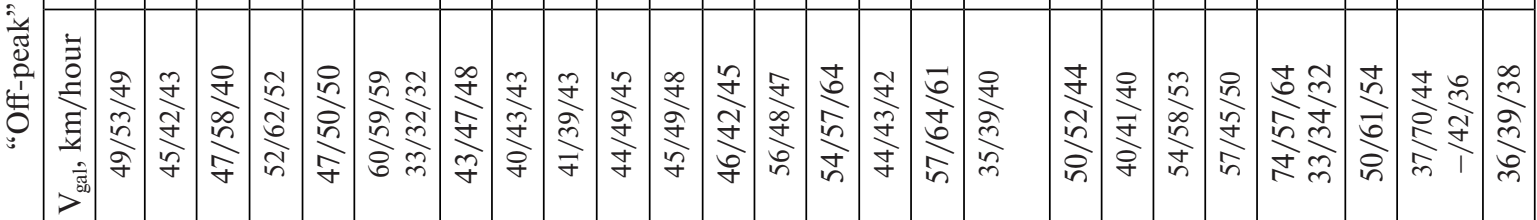

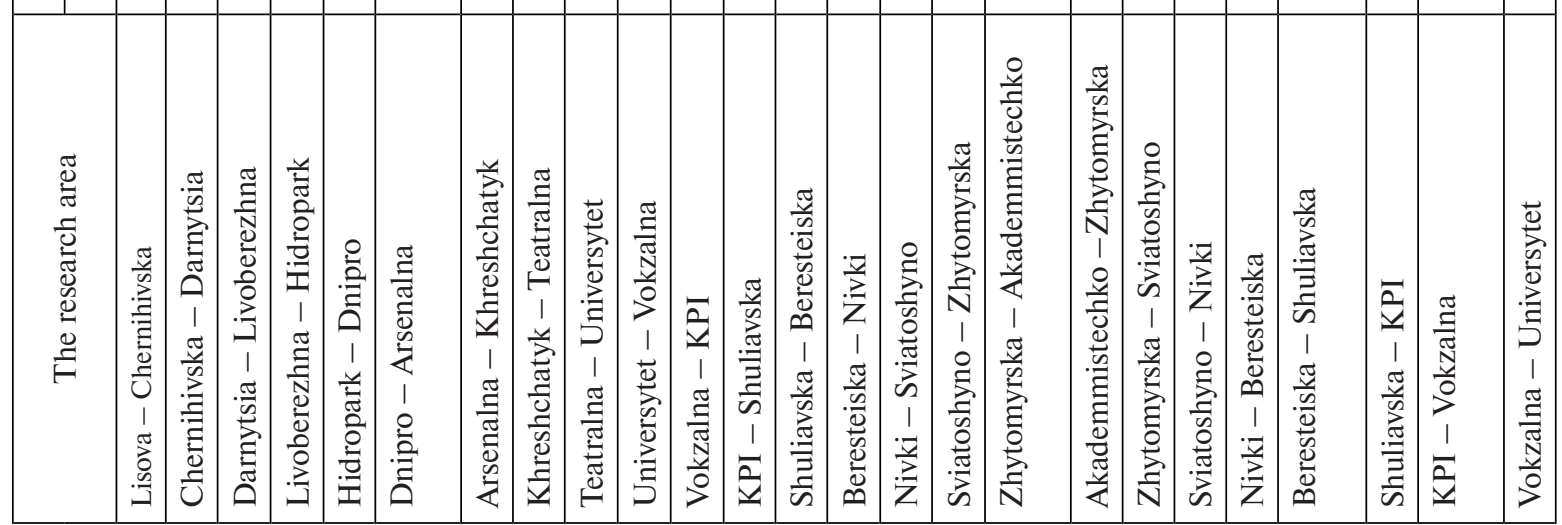




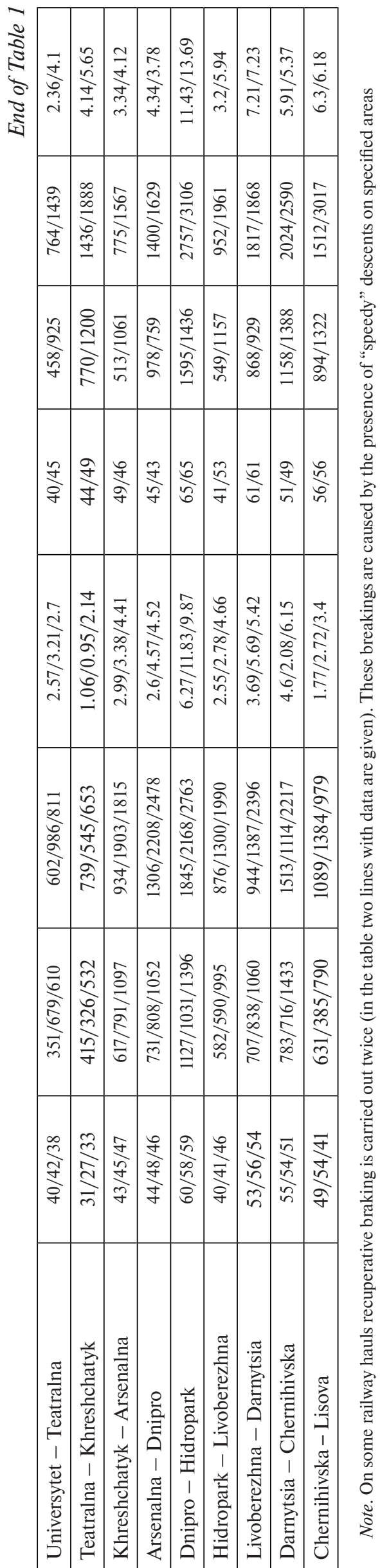



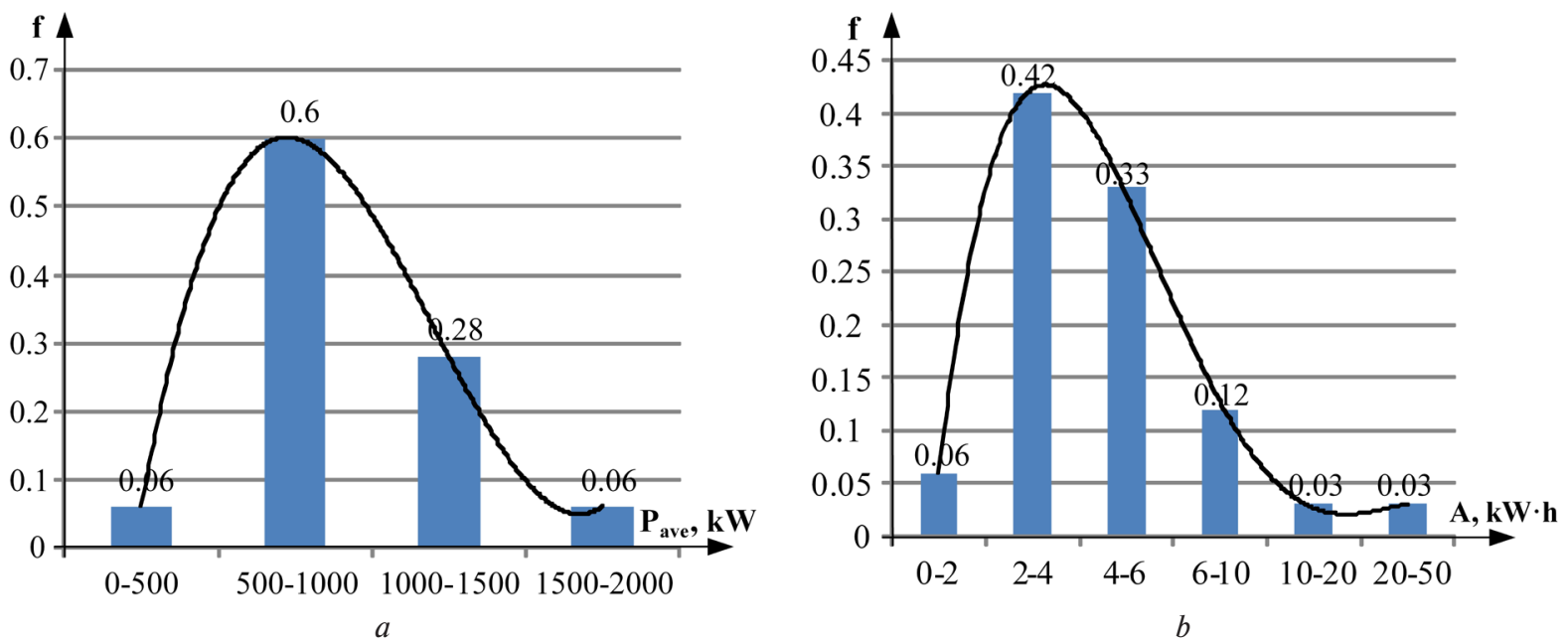

Fig. 1. The histograms of distribution density of the average power (a) and and the amount of recuperative energy (b) for the first approach
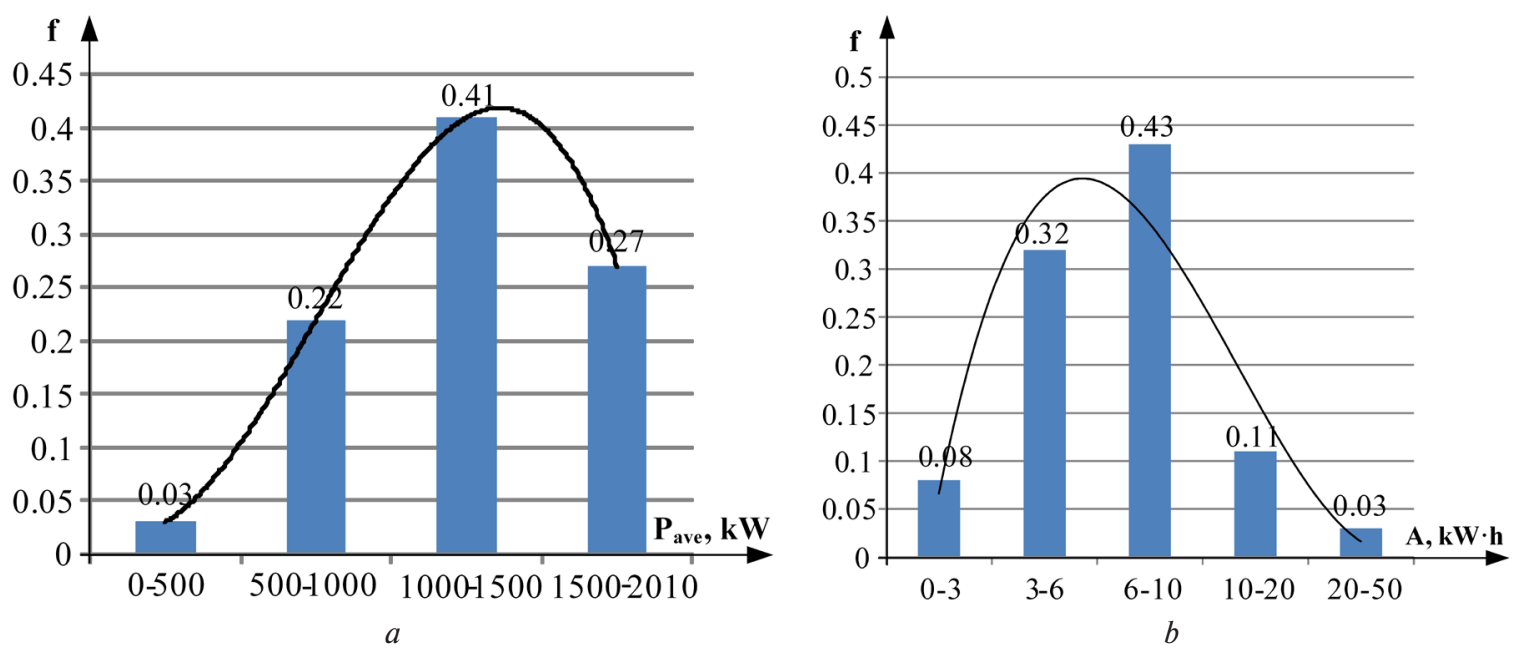

Fig. 2. The histograms of distribution density of the average power (a) and and the amount of recuperative energy (b) for the second approach
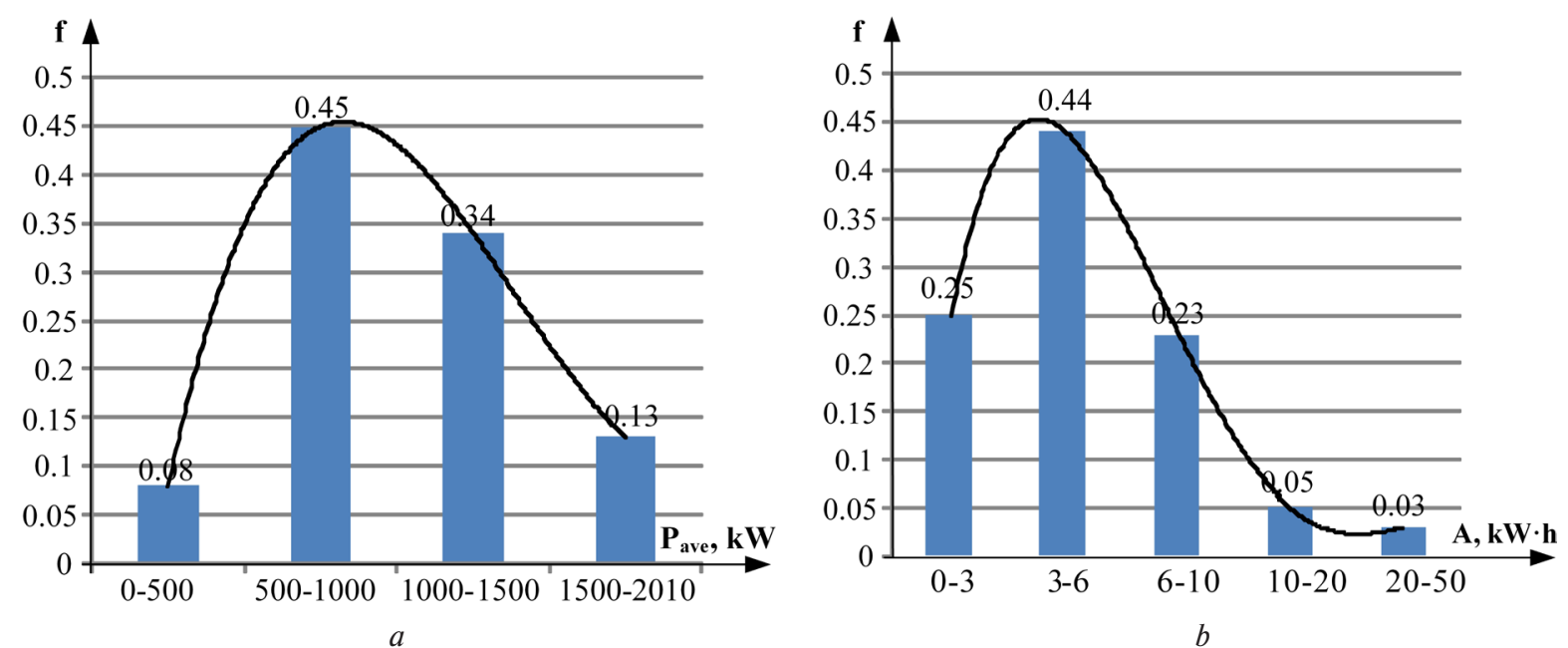

Fig. 3. The histograms of distribution density of the average power (a) and the amount of recuperative energy (b) for the third approach 
Table 2 3. Lovskaya, A. and Ryibin, A., 2016. The study of dy-

The results of the research

\begin{tabular}{|c|c|c|c|}
\hline Parameter & 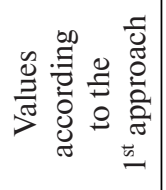 & 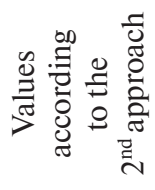 & 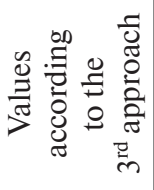 \\
\hline$A_{\text {ave }}, \mathrm{kW} \cdot \mathrm{h}$ & 4.58 & 6.58 & 4.84 \\
\hline$\sigma, \mathrm{kW} \cdot \mathrm{h}$ & 2.75 & 2.82 & 2.54 \\
\hline$P_{\text {nот.CES }}, \mathrm{kW}$ & 870 & 1314 & 1017 \\
\hline$P_{\max . C E S}, \mathrm{~kW}$ & 3112 & 3835 & 3879 \\
\hline$A_{C E S}, \mathrm{~kW} \cdot \mathrm{h}$ & 7.33 & 9.4 & 7.38 \\
\hline$A_{g e n}, \mathrm{~kW} \cdot \mathrm{h}$ & 8.43 & 11.28 & 8.49 \\
\hline
\end{tabular}

the maximum power of the capacitive energy storage $\left(P_{\max C E S}\right)$, the required energy intensity of the capacitive energy storage $\left(A_{C E S}\right)$, are given in Table 2 . Also Table 2 presents the value of the required total energy consumption of the capacitive energy storage in regurd to the accepted "inactive storage" of the drive at the level of $15 \%$.

Therefore, the values of nominal and maximum power, as well as the working and total energy intensity of on-board capacitive energy storage for the given conditions of operation of the train according to the first approach, should be respectively at the level of $870 \mathrm{~kW}$; $3112 \mathrm{~kW} ; 7.33 \mathrm{~kW} \cdot \mathrm{h} ; 8.43 \mathrm{~kW} \cdot \mathrm{h}$, for the second approach it should be at the level of $1314 \mathrm{~kW} ; 3835 \mathrm{~kW}$; $9.4 \mathrm{~kW} \cdot \mathrm{h} ; 11.28 \mathrm{~kW} \cdot \mathrm{h}$, for the third one it should be $1017 \mathrm{~kW} ; 3879 \mathrm{~kW} ; 7.38 \mathrm{~kW} \cdot \mathrm{h} ; 8.49 \mathrm{~kW} \cdot \mathrm{h}$.

Conclusions and recommendations for further research. The research studies were carried out on the basis of the offered approaches. As a result, the necessary parameters of on-board capacitive energy storage for the given modes of rolling stock with the recuperative systems were determined. According to the obtained data it has been established that for the indicated modes of rolling stock the nominal power of the capacitive energy storage should be within the range $870-1314 \mathrm{~kW}$, the maximum power of the capacitive energy storage is within $3112-3879 \mathrm{~kW}$, the energy intensity of the capacitive energy storage is within $7.33-9.4 \mathrm{~kW} \cdot \mathrm{h}$, total energy consumption of the capacitive energy storage is within $8.43-11.28 \mathrm{~kW} \cdot \mathrm{h}$.

Further research needs to be focused on developing a single complex approach that would allow determining the rational parameters of the capacitive energy storage (nominal and maximum power, working and total energy intensity) on the criterion of the minimum payback period.

\section{References.}

1. Zhemerov, G. G., Ilina, N. A. and Tugay, D. V., 2014. Reduction of energy losses in the rolling stock of underground power systems using energy-intensive electric drives. Tekhnichna elektrodynamika. Technical electrodynamics, 5, pp. 137-138.

2. Fomin, O.V., Burlutsky, O.V. and Fomina, Yu.V., 2015. Development and application of cataloging in structural design of freight car building. Metallurgical and Mining Industry, 2, pp. 250-256. namic load on a wagon-platform at a shunting collision. Eastern-European Journal of Enterprise Technologies, 3(7(81)),pp.4-8. DOI: 10.15587/1729-4061.2016.72054. 4. Ciccarelli, F., Iannuzzi, D. and Tricoli, P., 2012. Control of metro-trains equipped with onboard supercapacitors for energy saving and reduction of power peak demand. Transportation Research Part C: Emerging Technologies, 24, pp. 36-49.

5. Kolb, A. A., 2010. Storage of energy recovery electric transport by using capacitive energy storage. Bulletin of Dnipropetrovsk National University of Railway Transport named after academician V. Lazaryan, 31, pp. 89-94.

6. Fomin, O., 2015. Improvement of upper bundling of side wall of gondola cars of 12-9745 model. Metallurgical and Mining Industry, 1, pp. 45-48.

7. Kelrykh, M. and Fomin, O., 2014. Perspective directions of planning carrying systems of gondolas. Metallurgical and Mining Industry, 6, pp. 64-67.

8. Panchenko, S. V., Butko, T. V., Prokhorchenko, A. V. and Parkhomenko, L. O., 2016. Formation of an automated traffic capacity calculation system of rail networks for freight flows of mining and smelting enterprises. Naukovyi Visnyk Natsionalnoho Hirnychoho Universytetu, 2, pp. 93-99.

9. Kostin, N.A. and Nikitenko, A. V., 2014. Autonomy of regenerative braking - the bases of reliable energy efficient recovery for electric rolling DC. Railway transport of Ukraine, 3, pp. 15-23.

10. Donchenko, A. V., Muzhychuk, S. O., Sulym, A. O., Khozya, P. O. and Melnyk, O. O., 2015. A study of energy efficiency of a modernized train of the metro production of "KRCBW" PJSC. Proceedings of "Rail rolling stock”, 12, pp. 48-56.

11. Myamlin, S., Dailydka, S. and Neduzha, L., 2012. Mathematical modeling of a cargo locomotive. In: Proceedings of the $16^{\text {th }}$ International Conference "Transport Means”, Kaunas, pp. 310-312. Available at: < http:// eadnurt.diit.edu.ua/jspui/handle/123456789/2952 [Accessed 11 October 2017].

12. Gerlici, J., Mykola, M., Kravchenko, K., Kostyukevich, A., Nozhenko, O. and Lack, T., 2016. Experimental Rigs for Wheel /Rail Contact Research. Manufacturing Technology, 16(5), pp. 909-916.

13. Tartakovskyi, E., Gorobchenko, O. and Antonovych, A., 2016. Improving the process of driving a locomotive through the use of decision support systems. Eastern-European Journal of Enterprise Technologies, 5(3(83)), pp. 4-11. DOI: 10.15587/1729-4061.2016.80198.

14. Gerlici, J., Mykola, M., Kravchenko, K., Prosvirova, O. and Lack, T., 2017. The innovative design of rolling stock brake elements. COMMUNICATIONS, 19(2A), pp. 23-28.

15. Sablin, O. I., 2014. Research recovery efficiency of the electricity in underground conditions. East European Journal of advanced technologies, 8(72), pp. 9-13.

16. Bychkova, M.P., 2010. Energy saving in the metro. Transport of the Russian Federation, special issue Science and Transport. Subways future, p. 67. Available at: $<$ http://rostransport.com/transportrf/pdf/30-31/67. pdf $>$ [Accessed 29 September 2017]. 
17. Shevlyugin, M. V. and Zheltov, K. S., 2008. Reduced power consumption for the movement of trains in Moscow Metro using capacitive energy storage. $N T T-S c i-$ ence and technology of transport, 1, pp. 15-20. Available at: <https://elibrary.ru/item.asp?id=9951099> [Accessed 20 September 2017].

18. Lyubarskiy, B. G., Shayda, V.P. and Buryakovskiy, S. G., 2015. Comparative analysis of the energy storage devices for vehicles. Railway transport of Ukraine, 6 , pp. $13-21$.

19. Ciccarelli, F., Iannuzzi, D. and Lauria, D., 2012. Stationary ultracapacitors storage device for improving energy saving and voltage profile of light transportation networks. Transportation Research Part C: Emerging Technologies, 21(1), pp. 321-337.

20. Iannuzzi, D., Pagano, E. and Tricoli, P., 2013. The use of energy storage systems for supporting the voltage needs of urban and suburban railway contact lines. Energies, 6(4), pp. 1802-1820.

\section{Теоретичний i практичний базис визначення параметрів бортового ємнісного накопичувача енергії рухомого складу}

$$
\begin{gathered}
\text { А. О. Сулим }{ }^{1} \text {, О. В. Фомін }{ }^{2} \text {, П. О. Хозя } \\
\text { А. Г. Мастепан } \\
\end{gathered}
$$

1 - Державне підприємство „Український науково-дослідний інститут вагонобудування“", м. Кременчук, Україна, e-mail: sulim1.ua@gmail.com

2 - Державний університет інфраструктури та технологій, м. Київ, Україна, e-mail: fomin1985@ukr.net

3 - Український державний університет залізничного транспорту, м. Харків, Україна, e-mail: antonua86@gmail. com

У зв'язку з поетапним підвищенням тарифів за спожиту електроенергію подальший розвиток рухомого складу неможливий без застосування сучасних енергозберігаючих технологій та енергоощадних систем.

Мета. Подальший розвиток рухомого складу метрополітену із системами рекуперації в частині підвищення його енергоефективності за рахунок упровадження бортових накопичувачів енергії ємнісного типу з урахуванням зміни добових умов експлуатації.

Методика. Використовуючи результати експериментальних досліджень, а також застосовуючи статистичні методи обробки даних, методи аналізу й теорії ймовірності, запропоновані три підходи з визначення параметрів бортового ємнісного накопичувача. Запропоновані підходи передбачають послідовне виконання наступних спільних етапів: вибір ділянки експлуатації й моделі рухомого складу метрополітену, визначення штатних добових умов експлуатації, експериментальне дослідження енергетичних процесів під час різних добових умов експлуатації рухомого складу, обробка отриманих масивів даних, побудова гістограм і безпосередньо визначення параметрів бортового ємнісного накопичувача за запропонованими критеріями.
Результати. Виконана реєстрація енергетичних процесів під час штатних добових умов експлуатації дослідного рухомого складу із системами рекуперації на Святошинсько-Броварській лінії Комунального підприємства „Київський метрополітен““. Розраховані миттєва й середня потужності, а також кількість електроенергії для кожного рекуперативного гальмування поїзда. За результатами обробки масивів даних побудовані ймовірнісні характеристики у вигляді гістограм щільності розподілу середньої потужності та кількості електроенергії рекуперації для трьох запропонованих підходів. Із використанням зазначених підходів для заданих умов експлуатації поїзда метрополітену визначені основні технічні параметри бортового ємнісного накопичувача енергіі: номінальна й максимальна потужності, робоча й загальна енергоємності.

Наукова новизна. Уперше запропонованоі підходи з визначення параметрів бортового ємнісного накопичувача для поїзда метрополітену за аналізом характеристик щільності розподілу середньої потужності та кількості електроенергії рекуперації.

Практична значимість. Запропоновані підходи можуть бути використані при створенні рухомого складу метрополітену з бортовим ємнісним накопичувачем енергії.

Ключові слова: бортовий ємнісний накопичувач енергії, рухомий склад метрополітену, система рекуnераиіï

\section{Теоретический и практический базис определения параметров бортового емкостного накопителя энергии подвижного состава}

\author{
А.А. Сулим ${ }^{1}$, А. В. Фомин ${ }^{2}$, П.А.Хозя \\ A. Г. Мacmenaн ${ }^{3}$
}

1 - Государственное предприятие „Украинский научноисследовательский институт вагоностроения“, г. Кременчуг, Украина, e-mail: sulim1.ua@gmail.com; pavel.ua@ gmail.com

2 - Государственный университет инфраструктуры и технологий, г. Киев, Украина, e-mail: fomin1985@ukr.net 3 - Украинский государственный университет железнодорожного транспорта, г. Харьков, Украина, e-mail: antonua86@gmail.com

В связи с поэтапным повышением тарифов на употребленную электроэнергию дальнейшее развитие подвижного состава невозможно без применения современных энергосберегающих технологий и энергосохранных систем.

Цель. Дальнейшее развитие подвижного состава метрополитена с системами рекуперации в части повышения его энергоэффективности за счет внедрения бортовых накопителей энергии емкостного типа с учетом изменения суточных условий эксплуатации.

Методика. Используя результаты экспериментальных исследований, а также применяя статистические методы обработки данных, методы ана- 
лиза и теории вероятности предложены три подхода для определения параметров бортового емкостного накопителя. Предложенные подходы предусматривают последовательное выполнение следующих общих этапов: выбор участка эксплуатации и модели подвижного состава метрополитена, определение штатных суточных условий эксплуатации, экспериментальное исследование энергетических процессов во время разных суточных условий эксплуатации подвижного состава, обработка полученных массивов данных, построение гистограмм и непосредственно определение параметров бортового емкостного накопителя по предложенным критериям.

Результаты. Выполнена регистрация энергетических процессов во время штатных суточных условий эксплуатации опытного подвижного состава с системами рекуперации на Святошинсько-Броварской линии Коммунального предприятия „Киевский метрополитен“. Рассчитаны мгновенная и средняя мощности, а также количество электроэнергии для каждого рекуперативного торможения поезда. По результатам обработки массивов данных построены вероятностные характеристики в виде гистограмм плотности распределения средней мощности и количества электроэнергии рекуперации для трех предложенных подходов. С использованием отмеченных подходов для заданных условий эксплуатации поезда метрополитена определены основные технические параметры бортового емкостного накопителя энергии: номинальная и максимальная мощности, рабочая и общая энергоемкости.

Научная новизна. Впервые предложены подходы для определения параметров бортового емкостного накопителя поезда метрополитена по анализу характеристик плотности распределения средней мощности и количества электроэнергии рекуперации.

Практическая значимость. Предложенные подходы могут быть использованы при создании подвижного состава метрополитена с бортовым емкостным накопителем энергии.

Ключевые слова: бортовой емкостной накопитель энергии, подвижной состав метрополитена, система рекуперации

Рекомендовано до публікації докт. техн. наук М. М. Бабаєвим. Дата надходження рукопису 15.08.17. 